\title{
Um simulacro de SUS?
}

\author{
SUS: fact or simulation?
}

¿Un amago de SUS?

Jairnilson Silva Paim 1

doi: 10.1590/0102-311X00114418

É sempre com imenso prazer que leio os textos da Profa. Ligia Bahia, sejam acadêmicos ou jornalísticos. Além de revelarem uma inquietação intelectual que conduz a novos temas, questões e linhas de pesquisa, alcançam uma comunicação fecunda com os leitores e estimulam jovens a trilhar caminhos ousados para a investigação em Saúde Coletiva. A militância da autora nas entidades e no movimento da Reforma Sanitária Brasileira expressa seu compromisso ético e político em defesa do direito à saúde e do SUS.

Neste ensaio, Ligia reflete sobre a situação atual do SUS, desenvolvendo uma argumentação sustentada num referencial teórico crítico e numa base empírica que lhe possibilita ultrapassar o doxológico e o proselitismo vulgar que muitas vezes comprometem a qualidade dos textos de autores engajados nas lutas sociais. A autora não faz concessões. Não abre mão de considerar e investigar determinações estruturais sobre a organização social dos serviços de saúde, mas realça, igualmente, a reflexão e as ações dos sujeitos no espaço da política, contornando determinismos, com vistas em possíveis pontes entre estrutura e práxis.

Ao mesmo tempo em que critica muitos equívocos presentes em expressões acerca do SUS, algumas inclusive acionadas supostamente em sua defesa, brinda o leitor com informações relevantes que ajudam a desconstruir certos estereótipos e posições equivocadas. Demonstra que o SUS não é universal, nem é único, tendo crescido, contraditoriamente, com o sistema privado. Alerta que não há componentes homogêneos em nenhum desses setores, nem um ganha-ganha entre os mesmos, como sugere o discurso de empresários e dirigentes. Desse modo, o SUS como sistema público e universal formulado pelo movimento da Reforma Sanitária Brasileira desde 1979 é inviável se não forem priorizadas estratégias de "desprivatização". Os ataques e ameaças recentes reforçam a tese, de modo que essa política não é irreversível, podendo permanecer um SUS reduzido ou mesmo um simulacro ${ }^{1}$.

Registra a escassez de investigações destinadas a analisar o novo setor privado e filantrópico, examinando suas agendas, representantes e formas de atuação. Sugere um deslocamento do olhar investigativo mais diversificado, contemplando o "núcleo duro" do Executivo, o Congresso Nacional e o Poder Judiciário, entre outros. Iniciativas dessas instâncias têm revelado nessas três décadas opções contrárias ao desenvolvimento do SUS. Ou seja, o Estado brasileiro sabota a Reforma Sanitária Brasileira e o SUS. Como sublinha a pesquisadora, sem estudos e análises cuidadosos as disputas políticas e ideológicas reforçam a opacidade, limitando a reflexão e a prática política dos sujeitos.
1 Instituto de Saúde Coletiva, Universidade Federal da Bahia, Salvador, Brasil.

\section{Correspondência}

J. S. Paim

Departamento de Saúde Coletiva, Instituto de Saúde

Coletiva, Universidade

Federal da Bahia.

Rua Basílio da Gama s/n,

Campus Universitário

Canela, Salvador, $B A$

40110-040, Brasil.

jairnil@ufba.br 
Outra tese apresentada no texto instiga mais comentários. A autora reconhece que o SUS expressa uma conquista democrática, embora considere que o "bloco" a quem coube tal formulação teria perdido potência (ou poder?) para a implementação das políticas de saúde. Essa avaliação política demanda novas perguntas ou alguns complementos. Trata-se do conjunto heterogêneo de sujeitos e entidades do movimento sanitário ou de um feixe de forças econômicas e políticas que teriam composto um bloco histórico voltado para o desenvolvimento econômico e social na transição democrática? Se a perda de potência corresponde à atuação do movimento da Reforma Sanitária Brasileira, essa argumentação pareceria plausível, seja quando se compara o seu protagonismo com o dos gestores do SUS desde a década de noventa, seja quando se considera a articulação política alcançada por seus intelectuais e militantes com parlamentares, partidos, governadores, sindicatos, associações de bairros e entidades de saúde no processo constituinte. Todavia, se a referida perda diz respeito às forças econômicas e políticas que se movimentaram em torno dos projetos Esperança e Mudança e Democrático-popular na transição democrática, envolvendo partidos como PMDB, PSDB (dissidência do PMDB), PT, PC do B, PPS (dissidência do PCB), PSB, entre outros, e que tiveram a oportunidade histórica de exercer o poder no governo central 2, talvez a explicação não se localize na perda de potência mas em fenômenos como a revolução passiva e o transformismo 3,4 .

Em síntese, o estudo ora comentado não ignora a crise do capitalismo de 2008 e suas repercussões nos sistemas universais de saúde, nas restrições aos direitos sociais e nas perspectivas do SUS. Ainda assim, fornece elementos empíricos que indicam que a crise do SUS antecede a crise econômica mundial. Demonstra que os obstáculos do SUS passam pelo subfinanciamento e pela falta de prioridades dos governos, mas a sua explicação encontra-se além do âmbito setorial. Assim, as questões contemporâneas relativas ao desenvolvimento do sistema de saúde brasileiro não se esgotam no SUS, indo além do fenomênico e alcançando o plano das estruturas: os movimentos do capital na financeirização da saúde, sob a "dominância financeira" 5 .

O recurso à teoria crítica pode ser um contraponto ao neoinstitucionalismo histórico, especialmente à dependência de trajetória (path dependence) ou mesmo um antídoto ao viés da Gabriela de Dorival Caymmi: "eu nasci assim, eu cresci assim, eu sou mesmo assim, vou ser sempre assim..." Ao contrário, tal como o estudo elaborado por outra Gabriela 6, o texto de Ligia indica que há sempre espaço para a luta, para a conquista e redistribuição do poder, para o desenho de estratégias e para mobilizações, enfrentamentos e alianças, seja com o propósito de mudança ou de conservação. Apesar da determinação econômica, há espaços na política para a constituição de sujeitos, para a construção de contratendências e para a defesa da democracia e dos direitos sociais e políticos.

Entre as conclusões do artigo, a Prof. Ligia Bahia ressalta que os setores privados e filantrópicoprivados são radicalmente diferentes daqueles existentes na época da promulgação da Constituição Federal de 1988. Tornaram-se intensamente financeirizados, impondo seus interesses sobre o fundo público de modo antidemocrático e anti-SUS. Embora haja muitas dúvidas e nebulosidades na conjuntura, ficam evidentes os movimentos dos empresários do setor de assistência, bem como os vinculados às operadoras e administradoras de benefícios junto às forças de centro-direita. Isso dá uma ideia do tamanho do desafio que o movimento da Reforma Sanitária Brasileira tem pela frente. Aumenta a sua responsabilidade de contribuir com os esforços de aglutinação das frentes de esquerda, movimentos sociais, centrais sindicais, políticos e partidos progressistas, bem como das forças democráticas para a construção de um futuro próximo menos conservador e regressivo. 
1. Paim JS. Sistema Único de Saúde (SUS) aos 30 anos. Ciênc Saúde Coletiva 2018; 23:1723-8.

2. Paim JS. A Constituição Cidadã e os 25 anos do Sistema Único de Saúde. Cad Saúde Pública 2013; 29:1927-53.

3. Gramsci A. Cadernos do cárcere. v. 5. Rio de Janeiro: Civilização Brasileira; 2002.

4. Paim JS. Reforma Sanitária Brasileira (RSB): expressão ou reprodução da revolução passiva? Planej Polít Públicas 2017; (49):15-33.

5. Sestelo JAF. Planos e seguros de saúde do Brasil de 2000 a 2015 e a dominância financeira [Tese de Doutorado]. Rio de Janeiro: Instituto de Estudos de Saúde Coletiva, Universidade Federal do Rio de Janeiro; 2017.
6. Monteiro MG. Trayectoria y cambios de dirección em las políticas públicas: análisis de la reforma del sistema sanitario brasileño (19752015) [Tese de Doutorado]. Bellaterra: Departament de Ciència Política i de Dret Públic, Universitat Autònoma de Barcelona; 2016. 